\title{
La cocina de los chullpas. Representaciones del pasado e identidades en el presente a partir de la alimentación en los Andes
}

\author{
Francisco M. Gil García \\ Departamento de Historia de América II (Antropología de América) \\ Universidad Complutense de Madrid \\ fmgilgar@ucm.es
}

Recibido: 28 de septiembre de 2013

Aceptado: 3 de noviembre de 2013

\section{RESUMEN}

Tomando como marco de referencia la cuestión de las distancias y diferencias a través de la alimentación en los Andes, este trabajo aspira a contribuir a la definición de los chullpas (los gentiles, los antiguos) a partir de su comida y su cocina, considerando que ambos criterios proporcionan un contexto fundamental no sólo para entender su tiempo, su espacio y su persona, sino las claves que marcan la diferencia con las gentes actuales del altiplano central y sur andino.

Palabras clave: Chullpas, gentiles, cocina, antropología de la alimentación, Andes.

\section{The Cookery of Chullpas. Representations on the Past and Identities in the Present through Foods in Andes}

\begin{abstract}
Taking as reference the issue of distance and differences through food in the Andes, this work aims to contribute to the definition of chullpas (the gentiles, the ancient people) from their meal and their cookery, considering that both criteria provide a crucial context not only to understand their time, space and person, but also the keys that make the difference with current people of Andean central and southern highlands.
\end{abstract}

Key words: Chullpas, gentiles, cookery/cuisine, anthropology of food, Andes.

Sumario: 1. Introducción. 2. Dulce, salado y picante. 3. Chacras, pedregales y cultivos salvajes. 4. Ruines, avarientos y por ende hambrientos. 5. La cebolla en la sopa... o de lo crudo y lo cocido. 6. Hígado muy pasado, carne cruda y antropofagia. 7. Consideraciones finales. 8. Referencias bibliográficas.

«Cuando salió el sol, entonces [los chullpas] se han secao. Ahí mismo dicen. Así estén en la mesa sentaos. Así está, ahí quedaron» Sabina Ticona, Santiago 2001.

\section{Introducción}

De un tiempo a esta parte diversos estilos de vida saludable se empeñan en convencernos de que «somos lo que comemos». Sin embargo, para la antropología éste es un axioma antaño resuelto. Evidentemente la alimentación influye en nuestra salud, pero cabe decir que el aforismo - quizás sin pretenderlo- va mucho más allá: al elegir unos alimentos para convertirlos en comida, al reglar una cocina y unas maneras de mesa, al validar al cocinero, al discriminar a los comensales, al integrar todo ello en ritos y mitos, estamos creando una ideología que guiará nuestros comportamientos, discursos e idealizaciones socioculturales. Pensamos en la comida, pero también lo hacemos a través de ella, convirtiéndola así en fundamento simbólico de primer or- 
den. Y es que -tal y como sintetiza J. López (2008)- comida y cocina sirven así de marcadores de identidad, de pertenencia al grupo, de posición social, edad, género o hasta de oficio; contribuyen a construir el cuerpo y la persona; se derivan al campo de la salud, la enfermedad y las prácticas terapéuticas; se vinculan con la magia y la brujería; traspasan la religión; acaparan buena parte de lo festivo; trascienden al terreno del arte y del gusto; alcanzan el universo de la seducción, el placer, incluso la sexualidad; se ponen al servicio de las tradiciones inventadas. «Somos lo que comemos», sí, pero holísticamente hablando.

Desde esta perspectiva, podría decirse que somos lo que somos y como somos, porque comemos lo que comemos y como lo comemos. Por eso aquellos cuya comida o cocina son diferentes de las nuestras, serán distintos de nosotros; tanto que podríamos negarles la condición de civilizados, incluso la de humanos. Los habitantes de tiempos remotos, las entidades tutelares, los brujos y especialistas rituales, los espíritus, los bárbaros y los salvajes, los infieles, hasta los etnógrafos, cualquier forma de alteridad más o menos extrema, todos comerán y cocinarán diferente a nosotros, porque pertenecen a un mundo distante y distinto al de la gente, la verdadera gente.

Tomando como eje la cuestión de la (re)creación de las identidades del pasado en el presente, las páginas que siguen giran precisamente en torno a esta cuestión de las distancias y diferencias a través de la alimentación en los Andes. Para ello fijaré como extremos de la comparación la alteridad habitante del «tiempo de los chullpas» ${ }^{1}$ y una mismidad definida a partir de «lo andino» en general y propia de la comunidad de Santiago K (Nor Lípez, Potosí, Bolivia) ${ }^{2}$ en particular. En este sentido, mi objetivo en este trabajo será el de contribuir a definir a los chullpas a partir de su comida y su cocina, pues me parece que éstas proporcionan no sólo un contexto fundamental para entender su tiempo, su espacio y su persona, sino las claves que marcan la diferencia con las gentes actuales del altiplano central y sur andino.

Al sur del Salar de Uyuni, a 3.800 m.s.n.m., la comunidad de Santiago se ubica en el extremo norte del Altiplano de Lípez, descrito habitualmente como la parte fértil de una región considerada la más árida del país a consecuencia de su extrema sequedad y sus bajas temperaturas. Con aproximadamente 80 familias, en Santiago abundan los niños y los adolescentes -más de un cuarto de la población total-, y faltan los jóvenes, que suelen emigrar temporalmente para seguir sus estudios o para buscar trabajo,

\footnotetext{
1 Tiempo de los chullpas, también nombrado, según regiones, como tiempo de los antiguos, de los abuelos, de los abuelos viejos, de los gentiles, de la gentilidad, de los ñawpa machus, de los suq'a o soq'a machulas. En términos generales, un tiempo antiguo de oscuridad salvaje (penumbra, propiamente dicho), habitado por una humanidad de tamaño reducido que no conoció el Sol, de cultura muy rudimentaria, dotada de poderes mágicos, que pereció con la primera aparición del astro rey en el firmamento (a veces, identificado/confundido con el Inca, los españoles, Dios o Jesucristo), que permanece aletargada en nuestro espacio-tiempo en el escenario de las ruinas arqueológicas, que puede despertar de nuevo y que causa enfermedad y hasta la muerte a quienes no respetan sus restos. Iré perfilando y ampliando esta caracterización a lo largo del texto.

2 Pudiera pensar algún lector que, siguiendo una práctica frecuente en algunas etnografías clásicas, se está enmascarando aquí el nombre de la comunidad de Santiago K, cuando en realidad se trata de éste: la letra «K» responde a una antigua demarcación cantonal hoy en desuso, aunque mantenida todavía en algunos topónimos de Nor Lípez como parte incorporada a los mismos. Sin embargo, los santiagueños sólo utilizan este nombre completo a efectos oficiales, y ocasionalmente para diferenciar a su comunidad de la vecina Santiago Chuvica, de manera que, siguiendo los usos de la toponimia local, y a efectos prácticos de escritura y lectura, en lo sucesivo emplearé el nombre corto de comunidad de Santiago.
} 
a Uyuni, Potosí, Oruro, La Paz o al vecino Chile. Mayoritariamente los santiagueños hablan en español, mantenido el quechua por la gente de más edad -monolingües las mujeres, bilingües los hombres-, conocido por la población de mediana edad y casi perdido entre jóvenes y niños a pesar de los empeños oficiales por alcanzar una educación bilingüe; el quechua queda reservado para algunas fórmulas y letanías en los costumbres (rituales), para la conversación reverencial con los ancianos o para esa intimidad doméstica donde la presencia de un antropólogo puede llegar a resultar incómoda. No exaltan una identidad indígena u originaria, y tampoco la reivindican. No se dicen campesinos, aunque cultivan la tierra; ni pastores, aunque crían ganado, fundamentalmente llamas y, ayer más que hoy, algunos corderos. En suma, los santiagueños se sienten sólo eso: de Santiago; todo lo más, miembros de la (Gran) Tierra de los Lipes, entendida ésta no tanto como una región geohistórica sino como una mancomunidad desde la cual distintas poblaciones tratan de poner en marcha proyectos de desarrollo local autogestionados, básicamente desde la promoción turística de ruinas arqueológicas y parajes naturales.

A pesar de que desde la puesta en valor y uso del patrimonio arqueológico se estrecha un vínculo entre las comunidades del entorno regional y los chullpas, las gentes de Santiago no sólo no se consideran herederas de éstos, sino que identitariamente procuran distanciarse de ellos. De hecho, podría decir que en mis trabajos de campo entre 2001 y 2004 no me resultó fácil ahondar en ese tiempo de los antiguos más allá del relato breve que caracteriza a los chullpas como habitantes de un tiempo dominado por la Luna, que vivieron en las varias ruinas arqueológicas que hoy rodean la comunidad, y que murieron calcinados por los rayos de un Sol primigenio. Y sin duda, la clave para profundizar en su conocimiento la encontré muchas veces en la comida y la cocina... aunque no las de los chullpas, sino las mías propias. En este sentido, debo confesar que ocasionalmente yo mismo me vi convertido en nexo comparativo entre los chullpas y los santiagueños, generalmente más próximo a los primeros que a los segundos, sin duda por pertenecer ambos a ese mundo distante y distinto del suyo propio antes referido.

Es en este contexto como el testimonio de doña Sabina que inaugura estas páginas adquiere especial gracia (murieron los chullpas al salir el Sol allá donde estuvieren, «así estén en la mesa sentaos»). Junto con otras mujeres, ella estaba preparando la comida comunitaria que íbamos a compartir en el marco de un costumbre en honor al Señor de Quillacas, y yo me acerqué a interesarme por su labor y el menú. Me preguntó si ya había visitado las ruinas arqueológicas, y me regaló una breve relación sobre los chullpas, otra versión más del relato arquetípico de que vivían con la Luna y murieron al salir el Sol, con ese interesante detalle acerca de que algunos perecieron mientras se encontraban sentados a la mesa. Cuando quise indagar un poco más en este punto, sobre la cocina de los chullpas y si también ellos celebrarían banquetes como el que en un rato nosotros íbamos a disfrutar, simplemente sonrió, desvió la mirada y cambió de tema, como tantos, como tantas veces.

En Santiago no se habla habitualmente de los chullpas (como de tantas otras cosas, que parece como si no existieran, como si no pasasen). O mejor dicho, no se reflexiona sobre ellos o/ni sobre su tiempo; simplemente se mencionan oportunamente, cuando conviene apostillar respecto del orden moral de las cosas, la historia de la 
comunidad o la identidad de los comunarios, para ayudar a entender el presente, los valores dominantes, las formas sociales, la comida (la de ellos y la de los demás), etc. Como ya he dicho en otro lugar (Gil 2008; 2011), los chullpas, y más concretamente sus espacios, han dejado de dar miedo a los santiagueños, aunque les siguen preocupando e incluso imponiendo un cierto respeto que los más jóvenes se empeñan en disimular, porque los chullpas, «haberlos hailos».

Sin perder de vista estas complicaciones a la hora de indagar en los chullpas y más aún en su cocina, organizaré estas páginas a partir de «anécdotas culinarias» de mi trabajo de campo, convirtiéndolas en entradilla para abordar un estudio de la comida en el tiempo de los chullpas, primero desde el pensamiento local de Santiago, y a partir de ahí en términos andinos. En este sentido, por esta vez mi interés se centrará únicamente en la representación del pasado chullpa a través de sus comidas, no siendo mi intención ahondar en lo que constituye hoy en día el sustento de los chullpas entendidos como entidades tutelares del pasado habitando el espacio-tiempo presente. Apunta J. López (2001: 113) -por más que yo no esté de acuerdo con élque poco se puede llegar a saber de los chullpas, y que básicamente es a través de las terapias reparadoras de su mal como podemos llegar a conocerlos un poco mejor, resultando en ello clave sus gustos culinarios. Pues aún así, tampoco abordaré aquí las ofrendas presentadas de cara a garantizar unas buenas relaciones de convivencia entre los chullpas y la gente, o las mesas rituales preparadas en el contexto de la medicina tradicional indígena (v.gr. Fernández 1995; 1997). Más bien, como digo, me interesa llegar a los chullpas desde su comida y su cocina, transitando las diferencias que la gente se empeña en marcar entre sus gustos, sus hábitos gastronómicos, sus artes culinarias y sus maneras de mesa, y los suyos propios, fijando en realidad con ello una distancia identitaria y moral entre su mismidad y la alteridad que los chullpas representan. Y por eso este trabajo, en el fondo, se irá construyendo de retales, idas y venidas y fragmentos en apariencia inconclusos. Poco se ha escrito al respecto, y lo que hay, muchas veces, resulta reiterativo. Sin embargo, no pretendo establecer aquí reglas generales, compartiendo con C. Itier (2007: 28) y P. Sendón (2010: 141) esa llamada de atención respecto de que los chullpas constituyen al tiempo una realidad y una idealidad culturalmente tan heterogénea (per se y en función de sus representadores), tan cargada de matices, sutilezas y precisiones, que tratar de componer una síntesis reductora de ellos, su tiempo y su «mito» muy probablemente los desfiguraría por completo.

\section{Dulce, salado y picante}

Señala C. Pomeroy (1988: 149) cómo durante su trabajo de campo en Salinas (Bolívar, Ecuador) se convirtió en objeto de chismorreo frecuente por tomar, amén de «otras comidas no comestibles», la carne sin sal, igual que los brujos, los espíritus y los salvajes de las tierras bajas. Asimismo, A. Spedding (1993: 59) comenta que frecuentemente sus interlocutores del altiplano Boliviano y los yungas de La Paz le hicieron notar que su costumbre de tomar el café sin azúcar no era correcta. Pues bien, por lo que a mí respecta, muchas veces en Santiago observé miradas y soporté comentarios 
relacionados con el hecho de no añadir un extra de sal a la comida cuando el resto de comensales señalaban su sabor desabrido - por gusto más que por salud, tiendo a seguir una dieta baja en sal-, o referidos a mi gusto por el té sin azúcar. Generalmente eran niños a quienes sus padres reñían por abusar del azúcar en su leche o té, incluso en refrescos ya de por sí azucarados, quienes se daban codazos y comentaban en voz alta «mira, como chullpa toma», generando entonces una situación que a sus padres solía incomodar y que yo aprovechaba para bromear e intentar indagar en el tema. Pero por las mismas, cuando durante mi estancia de campo de 2004 a los pequeños Adrián y Damiana (5 y casi 4 años respectivamente) les dio por imitarme en esto de no endulzar el té, observé que eran sus padres, Justino Calcina y Eva Quispe, quienes les añadían azúcar en la taza sin que ellos se dieran cuenta; «porque es bueno para que los chicos crezcan sanos», decían, aunque para mí que sus verdaderos motivos estaban más próximos a esa idea que tantas otras veces me comentaron (tanto ellos como otros de mis interlocutores) de que así es como un cristiano ha de tomar su té ${ }^{3}$.

El principio latente en estas anécdotas reside en el hecho de que para los andinos sólo los verdaderos humanos consumen sal (y azúcar, que no dulce); algo que se hace mucho más evidente cuando se examina qué otros no lo hacen. Como matizan los campesinos de Antabamba y Aymaraes (Apurímac, Perú), «antes de nada, la sal, porque sin ella ningún alimento puede ser tal» (Concha 1975: 750), esto es, no puede ser alimento verdaderamente humano, no puede convertirse en comida.

Será entonces porque la sal pertenece al mundo completo y condimentado de Dios (Bouysse-Cassagne y Harris 1987: 51; Platt 2001: 664, 972; Robin 2008: 169-170), que su presencia en el bautismo contribuye a que el niño se torne completamente humano y pierda la condición de chullpa consubstancial al «feto agresivo» (sensu Platt $2001)^{4}$. Por eso los brujos y quienes tratan con los diablos no toman sal, consiguiendo así las capacidades necesarias para brujear y volar; y por lo mismo pueden ser

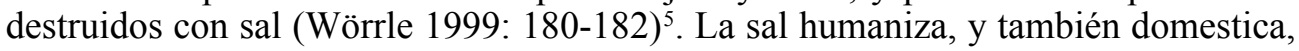
por eso se da a los ganados (domésticos) (Spedding 1993: 57-59; Wörrle 1999: 22, 181). Sin sal (de roca, todo lo contrario a la sal marina en estos términos), la sangre se volvería débil, delgada, fría; de ahí su importancia en las concepciones del cuerpo,

\footnotetext{
3 Respecto de esta aparente necesidad de ingesta de azúcar en beneficio de la salud, bajo la cual tal vez se camuflan otro tipo de ideas más ligadas al concepto de persona entre la población indígena andina, vale la pena recordar la viñeta cómica que el periódico boliviano La Razón publicaba al hilo del desabastecimiento de azúcar en los mercados en enero-febrero de 2011; una escasez de azúcar que ocasionó subida de precios y protestas de la población que no podía acceder a él. La viñeta presentaba a una mujer indígena, desdentada, quejándose por no poder comprar azúcar, y acompañaba la leyenda «las comunidades piden alimentos que dañan su salud». Evidentemente, quien emitía tal juicio, supuestamente «objetivo» desde un punto de vista médico, no estaba al corriente de la implicación y significación de los alimentos en la concepción andina de la persona. (Agradezco esta comunicación personal a Óscar Muñoz Morán).

4 A este respecto, P. Absi (2005: 113-114) apunta cómo el minero de Potosí procura no tomar sal en exceso ni introducir en la mina alimentos salados, porque la sal evocaría para él la sal del bautismo; ello convertiría -y no conviene- en especialmente «cristiano» a quien se mueve en el mundo subterráneo del Diablo, y cuya supervivencia depende en gran medida de éste.

5 Así como la sal puede utilizarse por parte de la magia blanca para anular e incluso destruir a estos personajes dañinos, R. Gow y B. Condori (1982: 28) apuntan que las gentes de Pinchimuro (Quipiscanchis, Perú) tratan la «enfermedad del hueso del chullpa» quemando éste con azúcar, esto es, endulzando por demás (caramelizando, podríamos decir en términos culinarios) a un ser que se caracteriza por no consumir azúcar.
} 
la salud y la enfermedad. Y por todo ello la sal ocupa un protagonismo en multitud de mitos, especialmente mitos de origen (Wörrle 1999: 163 y ss.).

Así por ejemplo, para los llameros de la puna de Moquegua (Perú) los habitantes del tiempo remoto previo a la salida del sol (esto es, los chullpas) no conocían ni la sal ni las llamas, elementos básicos no sólo en el modo de vida del altiplano, sino considerados indisolubles de la cultura, bisagra que separa al salvaje del civilizado (Wörrle 1999: 180) .

En términos culinarios -señala J. López (2001: 108)-, la sal permite singularizar y unificar al mismo tiempo los distintos sabores de un plato, de modo que sin ella lo cocinado mantiene una pluralidad heterogénea que impide que la comida sepa a lo que tiene que saber. En este sentido, sazonar los alimentos para dar sabor a la comida equivaldría, desde el mito, a sazonar la sociedad en busca de conjunción y armonía (Gutiérrez 1988: 298). Y lo mismo podríamos decir del azúcar, que no sólo sirve para endulzar los alimentos, sino que lo dulce remite también -simbólica e incluso etimológicamente-a las ideas de paz, mansedumbre, afabilidad, reconciliación de los desavenidos, amansamiento del furioso, etc. Por otra parte, su ausencia en las comidas igualmente implica salvajismo, de modo que tanto más cimarrón se es cuanto más desagrade lo dulce, como es el caso de los saxras (diablos) aymaras (López 2001: 109).

En síntesis, la gente debería de comer manejando con precisión las categorías de lo salado y lo dulce, pues ello es lo que la dota de su condición de auténtica humanidad. Por eso los chullpas comen sin sal, porque no pertenecen a esta humanidad, por mucho que pudieran parecerse a los verdaderos humanos. A este respecto $-\mathrm{y}$ tengo la impresión que cansado de mis preguntas en esta dirección-, Fermín Bernal Ticona (75 años, 2002) zanjó una de nuestras conversaciones sobre los chullpas apuntando:

«Como nosotros son. Únicamente no son... Sin sal saben comer $^{7}$. ¡Sin sal! Por eso son... ¡Muros ${ }^{8}$ son, pues! Sin bautizar. Nosotros, claro, comemos con sal; somos bautizados, cristianos. Ellos, muros, sin bautizar. Así no más son».

Pero no sólo la sal (y el azúcar) convierten los alimentos de los hombres en comida humana; también, y en igual grado, el ají. Así, según los esquemas semióticos de A. Spedding (1993: 59), la sal y el ají definen la comida del cristiano, de la gente, mientras que la comida sin sal ni ají, o es comida ritual ${ }^{9}$ o lo es de gentiles.

A este respecto, recuerdo una comida comunitaria en Santiago, posterior a la celebración de un costumbre, en la que se sirvió un guiso al que cada uno podía añadir

\footnotetext{
${ }^{6}$ No es casual que estos chullpas desconocieran la sal y las llamas, dos elementos estrechamente unidos en los Andes; según muchos mitos de origen, la sal se habría generado precisamente de la orina de la Llama Celestial, uno de los animales «sagrados» por excelencia dentro de las cosmovisiones andinas (cfr. Duviols 1974-76; Zuidema y Urton 1976).

7 En el uso local del español, la locución «saber + infinitivo» implica no tanto una habilidad sino un hábito; en este caso, saber comer sin sal supone comer desabrido por costumbre, con todas las implicaciones civilizatorias e identitarias que vengo planteando.

8 Sin entrar en más discusión lingüística, muru/muro provendría, tanto en quechua como en aymara, de la corrupción del vocablo castellano moro, en el sentido de hereje, gentil, no bautizado, tal y como enfatiza don Fermín.

9 Comida ritual en el sentido de aquella que se ofrece a diferentes entidades tutelares, o la que se consume como parte de un ayuno (ritual), puesto que ayunar no supone no comer, sino - tal y como establecen las reglas culinarias andinas ya desde época prehispánica- comer sin aderezar, como comería un auténtico ser humano.
} 
yasgua $^{10}$ a su gusto. Al tiempo que la salsa picante llegaba a mí, también lo hicieron las miradas expectantes de todos los presentes. A la pregunta insidiosa de $i_{i}$ Sabe comer yagua, Francisco?» yo respondí que sí, pues ciertamente no sólo la había tomado muchas veces antes, sino que gusto del picante y las especias. Aquella, sin embargo, era una salsa especialmente picosa cuya reacción en mis papilas gustativas provocó risas y bromas. Como yo había alardeado de saber comer, alguien, jugando con las palabras, dijo que más me valdría aprender. Pero el comentario realmente significativo provino de una voz anónima que equiparó mi manera de comer con la de los chullpas. Ya he señalado que en Santiago los chullpas no constituyen un tema de conversación, pero evidentemente, quedó patente que, para los santiagueños, los chullpas comían sin ají.

Tal y como plantearé en el siguiente epígrafe, los chullpas conocieron los mismos alimentos que las gentes de hoy en día, aunque en su variante silvestre, careciendo exclusivamente de dos cosas: la sal y el ají. De este modo -señala V. Cereceda (1990: 77)-, no sólo su comida, sino que ellos mismos habrían sido seres desabridos, lo que les convierte en la actualidad en entidades que, por no comer debidamente, pueden ser dañinas. Alteridades salvajes, sin condimentar, habitantes de un tiempo anterior a la Civilización (sensu Civilización Inca) ${ }^{11}$. A este respecto, tanto M. Rostworowski (2005: 215) como J. Ossio (1988: 565-566) llaman la atención sobre el dato de que dos de los Hermanos Ayar, ancestros de los incas, aludieran a estos condimentos en su nombre: Ayar Cachi (sal) y Ayar Uchu (ají). Sin entrar en matices -pues ello me alejaría bastante del objetivo de estas páginas-, no deja de ser significativo que estemos ante dos héroes culturales que, aunque fuera sólo de modo indirecto, habrían impuesto la civilización sobre la gentilidad a partir de la comida o, al menos, desde referencias culinarias.

\section{Chacras, pedregales y cultivos salvajes}

Septiembre de 2002. Patio de la casa de mis compadres Justino Calcina y Eva Quispe. Varios miembros de la familia extensa y yo mismo estábamos discriminando la cosecha de papas, descartando los frutos atacados por el gusano, seleccionando los que servirían de simiente para la próxima siembra, separando los que habrían de entregarse a los parientes ${ }^{12}$. Sobrellevábamos la tarea con animada conversación cuando alguien planteó la dureza de las labores de su siembra y cosechado en las laderas del

10 Yasgua (o llasgua, llasjua, llajua, llajwa): Aliño picante preparado básicamente de locoto (Capsicum pubescens), tomate, yerbas aromáticas y sal, al que se pueden añadir aceite, otros tipos de ají, cebolla, maní. Característico de la cocina boliviana (con variantes regionales), se consume también de manera tradicional en algunas regiones del noroeste argentino y del norte chileno.

11 Con múltiples variantes etnográficas, los chullpas fueron exterminados bien por el Sol, por el Inca, por Dios o por Jesucristo. En Santiago, más que el Inca fueron los incas quienes acabaron con ellos; unos incas que después de regalarles el conocimiento de la agricultura, la ganadería y el tejido, habrían terminado con los chullpas a cuenta de los abusivos trabajos con que habrían gravado el advenimiento de la paz y la civilización (Gil 2005).

12 La gente, a diferencia de los chullpas, sí comparte el producto de su trabajo y los frutos de la tierra. Volveré sobre este punto a su debido tiempo. 
cerro, como queriendo ilustrarme al respecto -dureza que mis riñones recordaban bien del año anterior, cuando colaboré en su cosecha en las chacras de la escuela-. «¿Cómo harían entonces?», fue su apostilla al intercambio de comentarios, una suerte de muletilla de las que en Santiago se usan para apelar al tiempo de los antiguos y sugerir explícitamente distancia con el presente. El abuelo Eniso Calcina sentenció que aquellos eran otros tiempos y otras papas. Ahí quedó todo, y pasamos a hablar de otros temas. Sin embargo, lejos de resultar baladíes, tanto la pregunta (retórica) como la sentencia remiten a una cuestión clave a la hora de abordar no sólo la alimentación de los chullpas, sino la caracterización de su mundo y la suya propia. Vayamos por partes.

En Santiago, como en buena parte del altiplano andino, se representan a los chullpas como enanos taumaturgos con poder sobre las piedras, y se asombran de que, a pesar de su reducido tamaño, fueran capaces de levantar las construcciones que a ellos asocian (torres funerarias, pukaras, murallas). Pero más aún se maravillan de los lugares donde los chullpas instalaban sus chacras, hoy auténticos pedregales incultivables. A este respecto me contó en cierta ocasión Erasmo Condori Ticona (60 años, 2002):

«No sé cómo lo harían, pero hay piedras grandes. Han debido de tener fuerza. $\mathrm{O}$ es que antiguamente todo era lo que ellos mandaban, todo se hacía ${ }^{13}$. Así cuentan, que ellos ordenaban. Con decir esas murallas... Hay lugares donde no hay piedras y hay murallas que están caídas. Ellos ordenaban, pues. Decían: 'A ver, ¿vas a producir, o no?', a la Pacha Mama, que decimos la Tierra. 'Sí, voy a producir'. Ah, entonces bueno, a sembrar. Sembraban. Por eso hay lugares por aquí... Hay chacras en lugares pedregosos, duros. ¿Cómo habrán sembrado en aquí? Pero sembraban. Nosotros en este tiempo estamos sembrando en las partes más blanditas no más, donde se puede cavar, pero esta gente antigua... iEn la parte dura sembraban no más! Para ellos decían así, que ordenaban a la Tierra. Preguntaban si iba a producir o no. Entonces... Sí, iba a producir. Decían: 'Que sea la muralla'. Entonces la muralla se hacía donde sea. Tenía que ser así».

Además de él, muchos de mis interlocutores se preguntaban igualmente cómo era posible que aquellos pircados derruidos, aquellos canchones pedregosos que proliferan en el piedemonte de los cerros que rodean la comunidad, y que tradicionalmente son asociados al tiempo de los chullpas, hubieran podido algún día ser fértiles campos de labor de donde éstos recogieran sus cosechas; parcelas, algunas de ellas, que

13 Es una constante en las tradiciones sobre los chullpas el destacar tanto su fortaleza sobrehumana como su poder sobre las piedras, las cuales moverían simplemente con el poder de la palabra. Más escasos resultan, sin embargo, los testimonios acerca de la implicación de los chullpas en modificaciones severas del paisaje, tales como cambiar montañas de ubicación o, a golpe de honda, abrir quebradas en los cerros o allanar montañas, así como trasladar tierras fértiles de un lugar a otro, e incluso alterar cursos de agua (Casaverde 1970: 154-157; Gow y Condori 1982: 27; Itier 2007: 28, 32-35, 37-38, 40-45; Martínez 2001; Nuñez 1957: 4-7; Voces de la Tierra 2010: 154). En este sentido -señala X. Ricard (2007: 118)-, machula (gentil) es un concepto que posee características o propias de los héroes culturales andinos, o asociadas a los grandes logros de la «civilización andina»; asumen entonces los chullpas un papel de héroe cultural arquetípico que generalmente corresponde al Inca, algo que -me parece- no deja de resultar paradójico cuando justamente se los está caracterizando como la antítesis del civilizado. 
incluso hoy siguen dando frutos de forma casi espontánea, silvestre ${ }^{14}$. Desde esta óptica, no sólo es que los chullpas fueran distintos de la gente, o que sus espacios hayan sido igualmente otros, sino que, paradójicamente, lo que en tiempos estuvo domesticado hoy es salvaje, lo que entonces fue Cultura hoy es Naturaleza ${ }^{15}$. Sin embargo, V. Cereceda (1990: 78-79, 98) llama la atención sobre el hecho de que traducir «lo chullpa» simplemente por «silvestre» no refleja plenamente la complejidad de esa lógica clasificatoria que distancia su mundo del de las comunidades actuales. No será pues -señala esta autora- un enfrentamiento entre Naturaleza y Cultura, sino entre una cultura y otra, el ego frente al alter, lo despierto y lo ensoñado, lo vivo y lo muerto. Así planteado, si lo que se pretende es alejar ambos universos y diferenciarlos en extremo, esos terrenos pedregosos que son interpretados como las chacras de los chullpas contribuyen a situar en el pasado un «reflejo silvestre» del mundo culturizado, civilizado, creando así un «efecto de realidad» que atestigua que aquel tiempo existió verdaderamente. Y ahí están sus restos -igual que las ruinas y los objetos arqueológicos, las momias, etc.-. Pero al mismo tiempo obliga a ambas épocas, a ambas culturas a enfrentarse día a día en el paisaje socialmente construido ${ }^{16}$. Como me señaló Wilson Condori Mamani (29 años, 2001) mientras me guiaba por entre las ruinas de uno de los sitios arqueológicos en la falda del cerro Qaral, uno de los dos mallkus de la comunidad de Santiago, precisamente conversando acerca de estos campos pedregosos y de los modos de vida de los antiguos: «exactamente no te puedo decir que han vivido así así, pero se ve que han vivido».

Hecho el apunte, y aún coincidiendo con Cereceda en este punto, mantendré aquí la dicotomía Naturaleza-Cultura y esa idea de que lo chullpa constituye un «reflejo silvestre» del mundo de la gente.

Remarcando la oposición entre civilización y barbarie, para Justino Calcina Lupa (41 años, 2002) los chullpas «aún no sabían qué era el cultivo, la siembra, todo ello, pero vivían más de caza. Por entonces había animales como ser la vizcacha, la chinchilla, el perdiz, y la vicuña, el guanaco, y entre muchos más otros animales existentes, que de ésos se alimentaban». En su relato de aquel tiempo, después llegarían los incas, que en su avance civilizador habrían regalado a los chullpas la agricultura; o mejor dicho, habrían introducido nuevos cultivos y les habrían enseñado a «labrar

14 Este prodigio, que para los santiagueños parece no ser sino una muestra más del poder de los chullpas sobre la Tierra, es interpretado desde multitud de tradiciones locales de Bolivia y Perú desde un prisma bien diferente, que tiene más que ver con su mezquindad y su renuencia a compartir sus bienes. Volveré sobre ello a su debido tiempo.

15 Conjugando estos criterios, convendría no perder de vista el dato recogido en algunas etnografías acerca de que las piedras que aparecen en estos campos constituirían en realidad los cultivos de los chullpas. Así por ejemplo, R. Rasnake (1988: 143) apunta cómo para los yura de Potosí (Bolivia) los chullpas habitarían un mundo de oscuridad, sembrando y cosechando bajo el influjo de la luna aquellas rocas que constituirían su sustento. Sin embargo, este mismo autor recopila un relato del ciclo de Tyusninchis en el cual este héroe cultural asimilable al Sol y a Jesucristo premia o castiga a quienes le ayudan en su huída de los diablos: al hombre que le muestra el debido respeto y le proporciona una coartada ante sus perseguidores, con excepcionales cosechas de maíz y papas; al chullpa que le trata desdeñosamente, intenta burlase de él y le delata, con una cosecha de puras piedras (Rasnake 1988: 144-145). Coincidentemente, los yuras son cultivadores de maíz.

16 Es por ello que, si los santiagueños han de atravesar estos terrenos para acceder a sus propias chacras, lo harán guardando el debido respeto, ofreciendo incluso algún pequeño pago, más aún si se trata de parcelas colindantes a otro tipo de restos arquitectónicos asociados al tiempo de los chullpas, y con más observancia si dichos restos quedan dentro de su chacra (Gil 2008 y 2011). 
con más capacidad», pues la economía chullpa ya estaba basada en la cría de rebaños y la agricultura. Contradicciones aparte (cfr. Gil 2005) resolvamos que los chullpas se mantenían sobre la base de otro modelo agropastoril, distinto del que practican los actuales santiagueños. Aunque quizás no tan distinto, como comentaré enseguida.

En realidad, lo que ocurre es que el mundo chullpa se inscribe en la Naturaleza; una naturaleza que aún no habría adquirido su forma definitiva y en la que lo animado y lo inanimado fluían entre sí, compartiendo hombres y animales unos atributos y capacidades intercambiables, confundiéndose lo domesticado y lo silvestre (Cavalcanti 2007; Cereceda 1990: 73, 75). Una indiferencia borrosa resultante de la oscuridad/ penumbra característica de aquellos tiempos antiguos presolares, y que la irrupción de la luz volvió nítida. Una «luz de Luz» -tal como reza el Credo católico- en el sentido que las gentes de K'ulta (Oruro, Bolivia), pastores aymaras de llamas, dan a ese Sol primigenio que aniquila a los chullpas, y al cual identifican con Jesucristo (Dillon y Abercrombie 1988); un Cristo-Sol que acaba con el dominio de las tinieblas y activa la distinción entre el día y la noche, las estaciones del año, los ciclos de creación y destrucción, de vida y muerte, y pone fin a la «subsistencia natural» de los chullpas. Una subsistencia en la cual no habría hegemonía cultural, dominación de la naturaleza, jerarquía entre lo natural y lo cultural. Por eso los chullpas pastorearían animales silvestres mientras que los k'ultas, por enseñanza del Divino Pastor, son pastores de llamas.

Y es que mientras mi compadre Justino (vid supra) señala que los chullpas cazaban animales silvestres, la mayor parte de tradiciones andinas señalan que los criaban, siendo así que los animales que para unos son hoy silvestres, para los chullpas habrían sido domésticos: las perdices sus gallinas, el zorro su perro, el zorrino o añasco su cerdo, la vizcacha su burro, las vicuñas sus llamas, etc ${ }^{17}$. Pero volvamos a las papas, y de ahí a esta suerte de taxonomía espejada en las plantas.

Antes señalaba que aquel día en Santiago estábamos separando papas para el consumo, para simiente y para compartir con los parientes, amén de descartando aquellas atacadas por el gusano. De manera similar, en Sonqo (Paucartambo, Perú) consideran que también los chullpas distinguirían entre tres tipos de papas: para comida, para semilla y para chuño (papa deshidratada) (Allen 1984: 155), creyendo además que son éstos (en su acepción de ancestros) los encargados de hacer crecer los distintos tipos de papa (Allen 1982: 183-185). Y de igual manera juzgan en Marcapata (Quipiscanchis, Perú), donde además estiman que los chullpas cultivarían diferentes variedades de papa (Solanum sp.), lisa u olluco (Ullucus tuberosus), oca (Oxalis tuberosa) y añu o mashua (Tropaeolum tuberosum) (Sendón 2010: 151-152, 158). Quizás por este motivo, porque los chullpas ya cultivaban estos tubérculos, en Pinchimuro (Quipiscanchis, Perú) dicen que los campesinos actuales tienen papas, lisas y añu; y por este motivo en los despachos destinados a ellos ofrecen de estos tres productos, aunque en tales casos la papa presentada sea papa podrida, ya que aunque los chullpas comen lo mismo que los hombres, no lo comen de igual manera (Gow y Condori 1982: 27).

17 A este respecto, V. Cereceda (1990: 75, 102) incide sobre el problema de la alpaca, algunas aves y varias especies vegetales que se situarían justo en el límite entre ambos mundos, presentes en el pasado y en la actualidad sin que pueda encontrárseles un «reflejo espejado» que indique su transformación de un tiempo a otro. 
Sin embargo, no en todas partes se reconoce a los chullpas tal riqueza en el consumo de tubérculos, ni se establece esta analogía entre sus cultivos y los de los hombres. Así por ejemplo, T. Platt (1986: 242) apunta que para los macha del norte de Potosí (Bolivia), el chuño habría sido la papa de los chullpas, seco, deshidratado, igual que los cadáveres que aparecen en el interior de las ruinas arqueológicas, desecados por ese Sol primigenio. Un chuño -junto con el charqui/charque, carne desecada de llama- que M. Dillon y T. Abercrombie (1988: 64) consideran como alimentos «chullpeados» que el hombre domina, y que a través de su rehidratación y/o cocinado convierte en comida de gente. En este sentido, bien podría decirse que el chuño constituye una suerte de alimento chullpa mantenido en este espacio-tiempo pero integrado al mundo de los hombres a través de la cocina: aún sin saber si los chullpas lo consumieron tal cual o luego de someterlo a algún proceso culinario, los verdaderos humanos exclusivamente lo consumen tras cocinarlo (sensu civilizarlo).

Cabría por tanto la posibilidad de hablar del chuño como el producto de un proceso para la conservación de la papa mantenido desde «tiempos antiguos» y estimado como uno de los logros de esa llamada «civilización andina». Como muestra, D. Arnold, D. Jiménez y J. de D. Yapita (1998: 129) señalan que las gentes de Qaqachaka (Oruro, Bolivia) apuntan a la awina (avena) salvaje y al $l u k^{\prime} i^{18}$ como único alimento de los chullpas. Sin embargo, y no sin cierta paradoja, los qaqas siguen cultivando hoy luk'i para chuño, que consideran a su vez la «comida del Inka», tal vez en memoria de las altas cantidades que de este producto debían tributar en tiempos del Tawantinsuyu.

Sin embargo, ejemplos como éste no hacen ni mucho menos que los tubérculos en general consumidos por los chullpas puedan recibir semejante trato de favor, ni siquiera la consideración de «papa antigua». Así, los campesinos de la citada comunidad de Marcapata consideran «antiguas» aquellas papas del «tiempo del Inca», ricas, sabrosas, bien aclimatadas al terreno, y las siguen cosechando, mientras que las papas del «tiempo de los chullpas», aquellas que crecen en los pedregales, resultan amargas, y por ello las desprecian (Sendón 2010: 156). Un desprecio-volveré sobre ello enseguida- que tiene además que ver con su dimensión moral: si estas papas crecen en los pedregales es porque los chullpas, sabedores de la inminencia de su extinción, por envidia de la humanidad venidera y por renuencia a que nadie pudiera disfrutar de sus bienes, optaron por destruir sus enseres de cocina y menaje, ocultar sus riquezas y arrojar a los pedregales su stock de alimentos, que seguirían brotando a partir de entonces como especies asilvestradas, «espejo» de los cultivos actuales. En este sentido -señala V. Cereceda (1990: 77)- es frecuente que tales plantas sean adjetivadas como ara, ajara o ayara, lo que remitiría a los míticos Hermanos Ayar con las connotaciones ya señaladas.

Así por ejemplo, la quinua ajara resultaría en realidad la cañigua (Chenopodium pallidicaule), especie silvestre que constituye quizás el ancestro botánico de la quinua domesticada (Chenopodium quinoa). Quinua y quinua ajara que tantas veces he visto ofrecer emparejadamente a los santiagueños en sus libaciones a los cerros y a

$18 L u k^{\prime} i$ : tubérculo ovalado, rosado y de sabor amargo, especialmente apreciado para su transformación en chuño. Sus diferentes variedades se caracterizan por una excelente aclimatación a terrenos altos de la puna y una alta resistencia a las heladas y a la escasez de humedad. 
las entidades tutelares que los habitan, en forma de pito $^{19}$; el preparado con quinua ajara específicamente destinado a los chullpas.

Respecto de ambas especies, Erasmo Condori Ticona (59 años, 2001) me comentó:

«crecen igual, a la misma altura. Por eso es que digo yo que nuestra quinua es la [quinua] ajara mejorada, nada más. Porque crecen igual. Porque hay de diferentes colores también, de la quinua y de la ajara también; igual es. Lo único es que de la ajara blanco no he visto; pero amarillo hay; hay rojo, hay rosada, hay negro. Igual que la quinua, la [ajara la] hay rojo, para hacer confitadas, pipocas ${ }^{20}$ decimos. También la hay como la quinua pequeñita, para la pisanqalla ${ }^{21}$ que sale negra. Y así. Por eso se cree que han sido agricultores».

A juzgar por esta descripción, quinua y quinua ajara no sólo resultarían prácticamente iguales en términos botánicos, sino que don Erasmo da incluso a entender que los chullpas consumirían (cocinarían) la cañagua de igual manera que hoy se hace con la quinua. Eso sí, cada quien con la quinua propia de su tiempo. Y por esta razón los campesinos actuales rechazan la cañagua, por más que mi interlocutor se empeñase en buscar otro tipo de raciocinios, quizás más científicos:

«Nosotros en este tiempo, la [quinua] ajara ya lo rechazamos. Ya nadie quiere comerla, ya nadie quiere coger, ni hacer producir, nada. Y es que no lo conocemos su valor nutritivo, aunque los que ya conocen dicen que el valor nutritivo es el mejor, mejor que la quinua incluso. A lo mejor es que no nos ha interesado producir. Sí, más bien es que lo estamos matando. Aparece en las chacras, y así como yerba mala lo sacamos, lo destrozamos. Ya no cultivamos. Pero la gente que sabe, en La Paz, por allí, dice que vale mucho más que la quinua, que esa quinua ajara vale más, porque tiene su valor nutritivo alto» (Erasmo Condori Ticona, 59 años, 2001).

Sea como fuere, a pesar de las enormes diferencias que en nuestras conversaciones don Erasmo solía marcar entre los chullpas y los santiagueños, no le cabía la menor duda de que, como lo eran ellos en el presente, también los antiguos habían sido agricultores, algo que, en el fondo, aproximaba la otredad de unos a la mismidad de los otros:

«los chullpas han sido agricultores también. Porque se ve. Todas esas partes de por ahí arriba, todas esas chullpas de ahí de Laqaya ${ }^{22}$, todo eso de por ahí. Así como nosotros tenemos en este tiempo para trillar quinua, así como nosotros hacemos unas bateas grandes de pura piedra, y ahí trillamos quinua, así. Ahora ya, claro, en la pampa no más tenemos, pero ellos en los cerros; esta gente trabajaba aquí en el cerro. Por eso es que pensamos que esa gente ha sido agricultor también. Ahí debió existir también la quinua a estas alturas. La quinua, la papa... se ve no más en estos cerros. En las partes más duras, donde no se puede sembrar, que nosotros no sembramos en esos terrenos,

19 Pito o pitu: bebida refrescante hecha con harina fina de quinua disuelta en agua, a la que se añade azúcar al gusto.

20 Pipocas: Quinua inflada, generalmente teñida de colores, que se consume como golosina por los niños.

21 Pisanqalla: Quinua tostada y reventada a modo de palomitas de maíz.

22 A medio camino entre las comunidades de Santiago y Santiago Chuvica, las ruinas arqueológicas de Laqaya se ubican al borde de una península rocosa en la falda del cerro Lliphi, dominando una fértil llanura agrícola actualmente destinada precisamente a cultivos de quinua. 
en ésos hay de esas pirhuas ${ }^{23}$ para guardar papa, en ésos hay para trillar quinua. Tienen pues. En esos que le llamamos kallanas ${ }^{24}$, donde se puede trillar la quinua, donde se desgrana la quinua. Y ésos tienen ahí, grandes, que en este tiempo tenemos como de la mitad no más. Así han sido. Han sido agricultores, han sido agricultores. Sí, así han sido, que vivían de eso. Claro, más antes, ¿cómo habría sido? Habrán sido nómades, pero luego se han establecido en lugares como aquí, como en Laqaya. Se han establecido y han sembrado sus papas, su quinua; ya no eran deambulantes; ya no caminaban de un lugar a otro. Ellos han sembrao, y [se] han establecido. Por eso ahí hay de esas kallanas» (Erasmo Condori Ticona, 59 años, 2001).

En algún punto de la larga conversación que mantuvimos acerca de los modos de vida de los chullpas, y en particular sobre sus sistemas económicos, duda don Erasmo si los chullpas habrían cultivado quinua o quinua ajara (cañagua) ${ }^{25}$, aunque lo verdaderamente importante para él fuera que habían cultivado. Incluso más aún, que, por el hecho de ser agricultores, los chullpas fueron asimismo sedentarios. Al mismo tiempo, regresando a los intereses de estas páginas, no deja de ser significativo el hecho de que estos chullpas desgranasen la quinua, algo significativo de cara a puntualizar -como haré más adelante- sus capacidades culinarias a partir del procesado de los alimentos como paso previo a su consumo, por más que éstos fueran alimentos silvestres.

\section{Ruines, avarientos y por ende hambrientos}

Señalaba al principio como rasgo más llamativo de la cocina chullpa su sabor desabrido por no utilizar sal, azúcar y ají, tres condimentos cuya ausencia en la dieta distingue al gentil del verdadero humano. Sin embargo, algunas tradiciones orales lo que enfatizan no es el desconocimiento o no utilización de estos ingredientes por parte de los chullpas, sino el hecho de que su rechazo al intercambio de bienes resulte significativamente marcado por su renuencia a compartir tanto estos condimentos como la cebolla, lo cual estaría expresando su negación de la Cultura (Rivera 2006: 141-142). Así por ejemplo lo enfatiza J. J. Rivera (2000) al analizar la historia de Elvira y el gentil de Llampa (Jauja, Perú).

A la niña Elvira siempre le advirtieron que no hurgase entre los restos antiguos, que no cogiera nada de las ruinas arqueológicas, que no molestara a «los antiguos», porque, de hacerlo, éstos se enfadarían con ella y le harían enfermar. La explicación dada a la protagonista de este relato es la de que los chullpas no quieren compartir

23 Pirhua: troje, granero o depósito de alimentos en general.

24 Está hablando don Erasmo de trillar o desgranar la quinua en estas como bateas de piedra que llama kallanas, cuando la quinua se suele trillar golpeándola con palos sobre telas o lonas, en las cuales se deposita el grano que a continuación se avienta para terminar de separarlo de la broza. La kallana en realidad es un recipiente para tostar cereales, semillas o ají; una gran bandeja rectangular de cerámica o metal, aunque con frecuencia, simplemente una olla vieja inservible ya para otro uso. Por otro lado, en Santiago alguna vez oí llamar kallana a unos morteros de piedra donde las mujeres muelen quinua con el talón del pie, práctica quizás más aproximada a la referida por don Erasmo. En cualquier caso, lo destacable del empleo de este término es el hecho de que los chullpas procesaban la quinua para convertirla en comida.

25 «Han sido agricultores, porque ahí, en todas esas partes, vemos kallanas para trillar quinua más que todo, ¿no? De ellos ha debido ser su quinua, o haya sido ajara no más, tal vez. No sabemos exactamente». 
con los humanos, pues ni siquiera habían compartido entre ellos, siendo ésta la causa de su desaparición:

«Antes, cuando se iba a pedir entre ellos, cuando se pedía prestado ají, sal, cebolla, no querían darse. Entonces ahora no te van a querer dar, no agarres sus cosas, no le saques sus cosas. [...]. Dios castigó [a los gentiles] porque eran malos. Así sería su carácter. No querían prestar ni siquiera un poco de ají. Por eso es un pecado muy grave negarse a prestar cebolla; es pecado mortal. [De haberlo hecho] Quizás el gentil estaría vivo, o su alma estaría viva, no sé» (Rivera 2006: 141-142).

Ella desatendió estos consejos, robando al chullpa parte de su vajilla (restos arqueológicos) simplemente para jugar, tirándola luego por ahí; también se llevó parte de la leña que éste tenía acumulada. En venganza, el chullpa, avaricioso, actuó como «el victimario de una acaparadora», contraatacando en el plano de la comensalidad, arrebatando a Elvira la capacidad de alimentarse; agarrando a su víctima, le aprieta la garganta, como si le estrangulara, impidiéndola así tragar cualquier tipo de alimento, líquido o sólido. En contrapartida, para lograr su curación, la comunidad entera aporta la «comida» con que se ha de preparar la soga con que se arrastrará al gentil fuera de Llampa, porque la gente sí intercambia, comparte, dona; ésa es una de sus características como tal (Rivera 2000: 277-279).

Atendiendo a la mezquindad de los chullpas desde otro prisma, su avaricia y su renuencia al intercambio de bienes podría llevarles incluso a negar a los demás las condiciones para la supervivencia. En este plano abundan las tradiciones donde se habla de chullpas castigados, de uno u otro modo, por diversas entidades tutelares superiores, por negarse a compartir las fuentes de agua, por robar el agua a otras comunidades o por impedir que ésta les llegase, por aventar sobre los campos de los otros semillas de malas yerbas y de buenos cultivos sobre los propios, o por robar tierra fértil a los vecinos para enriquecer con ella sus campos (Casaverde 1970: 154155; Itier 2007: 27-29, 32-35, 37-38; Voces de la tierra 2010: 154). Por eso su tiempo es caracterizado desde la escasez, los campos marchitos, los baldíos, desde imágenes evocadoras de la oscuridad salvaje, inhóspita y estéril del Purun o Puruma ${ }^{26}$ (Cereceda 1990: 77; Itier 2007: 29).

A la vez -sin perder de vista la heterogeneidad de la propia génesis cultural del chullpa/gentil, a la cual contribuyó la evangelización colonial tanto como hoy lo hace la prédica evangélica-, esta que podríamos llamar competencia desleal por los recursos, también hace posible que los chullpas puedan en ocasiones llegar a ser identificados como ancestros protectores de las comunidades, guardianes de sus recursos y, por ende, garantes de su supervivencia. En este sentido, G. Martínez (2001: 142-143) apunta que «en el mundo andino [los chullpas] connotan siempre fertilidad», equiparándolos a una Pachamama y un Diablo con los que compartirían un poder genésico y fecundador que los convertirían en «deidades de la fertilidad y de la abundancia».

26 Purun o Puruma: en las tradiciones quechua y aymara, y muy a grandes rasgos, tiempo o edad caracterizado por la oscuridad y la penumbra, las tierras en barbecho o baldías, estériles y secas, la escasez, los animales y plantas silvestres, sin domesticar, la naturaleza virgen. Sus habitantes, gentes de condición salvaje o asilvestrada, constituyen un pueblo indómito, entregado a la guerra total, carente de gobierno y policía, sin Ley ni Rey, que se sustenta de la caza-pesca-recolección, sin conocer la agricultura, la ganadería ni el tejido, logros civilizatorios que, generalmente, les enseñarán los incas; suelen ser identificados con los gentiles o chullpas. 
Pero más paradójico aún puede resultar el testimonio recogido por P. Sendón (2010: 153-154) en Marcapata (Quipiscanchis, Perú): los chullpa serían avariciosos y renuentes al intercambio, sí, pero al mismo tiempo trabajan unidos («en el tiempo de los ch'ullpa todos asistían, todos o nadies», persiguiendo y castigando al perezosos y al ocioso) para arreglar y fertilizar sus terrenos, razón por la cual los actuales marcapateños pueden seguir cultivando sus campos y recogiendo el fruto de aquellas simientes que los chullpas arrojaron a los pedregales como muestra de su despre$\mathrm{cio}^{27}$ por la humanidad venidera. En línea con esta imagen del chullpa fertilizador, J. Casaverde (1970: 157) cita cómo en Kuyo Grande (Cuzco, Perú) consideran a los chullpas no sólo como aquellos que dotaron a la comunidad de «tierras más dulces y fructíferas» traídas de lejos, sino como responsables de la buena crianza de habas y maíz. Porque había un chullpa que cultivaba hermosas habas, la comunidad producía las mejores de toda la región; agraviado éste por los daños ocasionados a sus restos, una noche cargó todas sus habas en un venado y se marchó; desde entonces en Kuyo Grande sólo se cogen habas raquíticas y de baja calidad. Lo mismo ocurriría con una preciada variedad de maíz, que se está perdiendo, lo cual lleva a pensar a los comunarios que el chullpa responsable de ésta les haya abandonado. Al margen de la consideración que en Kuyo Grande tienen de los chullpas como ancestros benefactores, y más allá de ambos sucedidos, retengamos el dato de que éstos cultivan habas y maíz.

No es mi intención ahondar aquí en el ocaso de los chullpas y su exterminio, ya sufrieran el castigo (divino) del Sol, el Inca, Dios o Jesucristo, bien por revelarse contra cualquiera de ellos, bien como escarmiento por su mal comportamiento; éste es quizás el tema estrella de la mayor parte de etnografías que tratan de los chullpas. Más bien quisiera incidir en ese hecho de que, sabedores de que se les acercaba el final, lejos de enmendar su actitud, los chullpas tratan de ocultar sus riquezas y destruir sus bienes para no tener que compartir con las generaciones venideras, tal y como ya he comentado. En este sentido -señalan J. Ansión (1987: 88-91) y C. Itier (2007: 29)-, igual que hiciera la prédica colonial, la tradición oral suele servirse de los chullpas para condenar comportamientos que amenazan la organización y la reproducción comunitarias: el acaparamiento de productos/recursos y el rechazo al intercambio de los mismos. Una condena moral que puede resultar reforzada -cuando no amplificada- por el hecho de que, negándose a compartir, habiendo destruido sus enseres de cocina, y tras arrojar sus alimentos a los pedregales, los chullpas se quedaron sin comida y sin posibilidad de cocinar... y tuvieron que recurrir al canibalismo. Volveré sobre ello más adelante, profundizando ahora precisamente en esa capacidad de cocinar presupuesta a los chullpas desde diferentes tradiciones.

\section{La cebolla en la sopa... o de lo crudo y lo cocido}

Recapitulemos. Por un lado, están los que señalan que los chullpas comen sin sal, ni ají, ni cebolla, porque no conocen estos tres ingredientes básicos de la cocina andina.

27 Tal y como señala J. J. Rivera (2000: 277 n. 15), en el español de los Andes, «despreciar» resultaría equivalente a una actitud renuente al intercambio entendida desde la ruptura de unas relaciones sociales amparadas en la Teoría del Don. 
Por otro, desde esa idea de los productos «espejados», V. Cereceda (1990: 77) señala que los chullpas cultivaron (y comieron) de todo, incluso cebollas, por más que éstas fueran silvestres y distintas a las que siembran y cogen los campesinos actuales. Y por último, están quienes apuntan que los chullpas no intercambian ni sal, ni ají, ni cebolla, lo cual presupone no sólo que conocen estos ingredientes sino que además los utilizan en su cocina. Cebolla y más cebolla.

Como la mayoría de niños, mi ahijado Adrián y sus hermanos solían tomarse su tiempo en expurgar bien el plato antes de empezar a comer; generalmente, sobre todo él, eliminaba de manera sistemática la cebolla ${ }^{28}$. Tantas veces he visto a mi comadre Eva Quispe (34 años cuando la conocí en 2001) regañarle por ello... «Cebolla vas comer. Si no, chullpa te vas volver», o «Mira, el Francisco sabe comer cebolla. Si comes cebolla, tan alto vas crecer. Si no, chullpa te vas volver». Volverse chullpa en el sentido de no crecer, de quedarse consumido a semejanza de esos cuerpos abrasados por los rayos solares primigenios que aparecen en el interior de las estructuras chullparias, huesos y piel seca. En este sentido, que Eva instase a Adrián a comer cebolla para no volverse chullpa bien podría entenderse como una amenaza para obligar al niño a comer un alimento que realmente no le gusta, más cuando esas mismas afirmaciones se las escuché idénticas en alusión a la sopa, de la que el niño tampoco era muy amigo. En alguna ocasión pregunté a mi comadre sobre esta cuestión, si es que acaso los chullpas no comían cebolla, o si mantenían algún vínculo especial con este bulbo, o qué pasaba con la sopa, pero ella, poco dada a hablar de estas cosas, siempre me contestaba lo mismo: que al chico no hay manera de hacerle comer cebolla, y ni asustándole así se consigue que la pruebe.

Pero ésta no es la única madre en Santiago a la que escuché meter miedo con los chullpas a la hora de comer, muchas veces convirtiéndome en extremo contrario de una comparación: si no comes esto o aquello, «chullpa te vas volver» (pequeño te vas a quedar, no vas a crecer), pero si lo haces, «como el Francisco vas a ser» (alto, crecido). Siempre sin encontrar una explicación que satisficiera mi curiosidad por los hábitos alimentarios de los chullpas. Siempre, hasta que un día presencié cómo Crescencia Mullo (30 años, 2002) amenazaba en estos términos a su hijo Roy por quitar la cebolla de la sopa - ¿qué tendrá la cebolla en la sopa?-. Ella se rió ante mi pregunta de si es que acaso los chullpas no comían cebolla, como si fuera lo más obvio del mundo, pero aún debí de parecerle más ignorante cuando le pregunté si comerían sopa; «ipues que van a comer si no?», me respondió. Ni mi pregunta era tan cándida, ni su respuesta resulta tan elemental. Vayamos por partes.

Es una afirmación frecuente en materia de antropología de la alimentación en los Andes que nada se come crudo; todo se pela, o se pica, o se corta, o se muele... y pasa las más de las veces por un proceso de cocinado recurrente: el hervido (Camacho 2006; Pazzarelli 2010; Spedding 1993 y 1994; Weismantel 1994). Tal es así que A. Spedding (1993: 56) concluye que, en términos generales, la cocina andina «parece tener como idea central cocinar hirviendo los alimentos en una olla». En este sentido, la sopa se convierte en el alimento más importante. Servida al menos una vez por día

28 Dentro de la gastronomía local, la cebolla suele añadirse a la sopa para que hierva, aunque también se sirve cruda como acompañamiento de los platos de arroz o, cuando se consiguen hortalizas, formando parte de una ensalada. 
cuando no dos, la sopa encarna, semióticamente hablando, el prototipo de «alimento húmedo», representando el hogar, lo cercano, el adentro, a la familia reunida, a la mujer, a «lo rico» (mish'i en aymara) (Pazzarelli 2010: 168-169; Spedding 1993: 56). Quizás por eso para doña Crescencia resultaba tan obvio que los chullpas tomaran sopa; interpretando su respuesta desde la cotidianidad, no hay otra forma entendible de comer que no incluya la sopa. Por otro lado, digo yo, considerando la caracterización de los chullpas como entidades secas, abrasadas por el Sol, ¿acaso podríamos pensar en un alimento mejor para ellos que la sopa, húmedo, hidratante? Sin embargo, ya dije que la respuesta encerraba su intríngulis.

H. Tschopik (1948: 113-114) caracteriza a los chullpas como seres paganos que cultivan sus campos en la oscuridad de la noche, que no saben cocinar y que toman los alimentos crudos. Una caracterización esta de que los chullpas ignoran las artes culinarias que prolifera en muchos de los estudios sobre ellos. Así por ejemplo, M. Dillon y T. Abercrombie (1988: 57) señalan que, en tanto que seres salvajes que viven en un estadio natural (no civilizado), los chullpas no saben comer comida (de gente), algo que ilustran con el siguiente relato recopilado en K'ulta (Oruro, Bolivia), según el cual un viajero (que en realidad es un chullpa) recibe hospitalidad de una pareja que le ofrece un plato de sopa de quinua. Al despedirse, les advierte que nunca vayan a visitarle ${ }^{29}$. Sin embargo, tiempo después, el hombre acude en su busca para devolverle la visita. Al llegar al lugar donde se supone que debía de estar su casa, sólo halla ruinas y un montón de huesos desecados; entre los huesos estaba la sopa de quinua que él y su mujer habían ofrecido al viajero, ni siquiera digerida.

En este sentido, en tanto que los chullpas consumen alimentos silvestres sin cocinar (crudos), la idea de que no saben comer -señalan estos mismos autores-implica más bien que no son capaces de digerir la comida humana (cocida), algo que -como también apuntan J. M. Arguedas (1960-61) y J. J. Rivera (2006: 156-161)- les equipara a los condenados, igualmente seres codiciosos y mezquinos. Ambos, chullpas y condenados, por más que puedan habitar en este mundo, jamás podrán hacerlo como los humanos.

La cuestión podría pasar por el hecho de que en algunas caracterizaciones del «tiempo de los chullpas» se dice que éstos, en su salvajismo, no conocían el fuego ${ }^{30}$. Sin embargo, T. Abercrombie (2006: 402 y ss.; Dillon y Abercrombie 1988: 56 y ss.), a partir de la tradición de K'ulta, matiza que no es tanto que no conocieran el fuego, sino que no podían controlarlo, capacidad exclusiva de Tatala (Dios-Sol). De este modo, teniendo fuego, ¿por qué no iban a poder cocinar? Y es aquí cuando su cocina se torna en sopa, o viceversa, señalando T. Platt (2001: 653) que para los macha del norte potosino (Bolivia) la comida predilecta de los chullpas era una sopa espesa

\footnotetext{
29 Nótese en esta advertencia la renuencia del chullpa a mantener contacto social, y sobre todo a ofrecer/ devolver hospitalidad, algo que podríamos ligar con esa caracterización antes descrita como ser avaricioso, ruin y mezquino que busca deliberadamente salirse del pacto social.

30 Se me viene a la memoria el comentario que un vecino de Humahuaca (Jujuy, Argentina) me hiciera en 1997 mientras conversábamos sobre la antigüedad del sitio de Santa Bárbara: en siendo antiguas, aquellas ruinas no lo eran tanto, puesto que aparecían restos de fogones que evidenciaban claramente que sus habitantes ya conocían el fuego, «no como los gentiles, que no lo conocen y se hacen la guerra con palos», dos claras alusiones a su primitivismo/salvajismo.
} 
llamada qalapari (o qalapurqa), calentada con tres piedras introducidas dentro de la olla. ¿Por qué entonces insistir en que los chullpas comen crudo y no saben cocinar?

$\mathrm{Tal}$ y como he señalado anteriormente, diversas tradiciones recogen el hecho de que los chullpas, sabedores de que su final estaba cerca, prefirieron romper su menaje de cocina antes que legarlo a la humanidad venidera. En el marco de esta tradición, por ejemplo, las gentes de Marcapata (Quipiscanchis, Perú) reconocen que 1) los chullpas tenían morteros, batanes, piedras de moler, cucharones, ollas, esto es, que estaban bien pertrechados para el procesado de alimentos y su transformación en $\mathrm{co}$ mida, e incluso que 2) llegado el caso, para paliar el hambre extrema, cocinaron a sus hijos; sin embargo, los consideran ignorantes de la cocina (Sendón 2010: 152-162). La clave, sin duda, está en que los alimentos por ellos «cocinados» (productos silvestres y sus propios hijos) no son realmente comida de gente. No es por tanto que los chullpas no sepan cocinar, sino que, como ya he mencionado varias veces, no saben hacerlo debidamente, no saben hacerlo como los verdaderos humanos. Eso es lo que fundamentalmente remarca su otredad, por más que ellos también -iy qué si no?, que diría doña Crescencia- tomen sopa ${ }^{31}$.

Pero más aún, no es que los chullpas coman «crudo» en estos términos que acabo de acotar, sino que ellos mismos, en tanto que silvestres, también representarían lo crudo. Sin embargo, sea como fuere, si el final del tiempo de los chullpas viene a representar la aparición sobre la Tierra de las especies botánicas y animales que las actuales gentes de los Andes conocen, cultivan y crían (Cereceda 1990: 76 y ss.), una domesticación de la Naturaleza en suma, su propio final habrá de entenderse como una civilización de su condición silvestre (Gil 2005). El Inca, Dios o Jesucristo, no lo olvidemos, regalan a los chullpas la agricultura, la ganadería y el tejido. Ahora bien, sin perder de vista el referente culinario, esta domesticación/civilización de los chullpas implicaría también un tránsito de lo crudo a lo cocido. Al morir abrasados por el Sol primigenio (sol necesario para la agricultura) o por el castigo divino enviado en forma de diluvio de fuego (fuego necesario para cocinar), los chullpas mueren cocinados en sus propias casas. Y ese proceso es el que los perpetúa y materializa en el espacio-tiempo actual, convertidos en cuerpos estáticos desecados en el interior de las ruinas arqueológicas. Unas casas que -apuntan Dillon y Abercrombie (1988: 61-62) - es como si estuvieran preconizando su propio final. Unas casas éstas del «tiempo de los gentiles» muchas veces descritas como pucullos.

En este sentido, los autores coloniales hablan de pucullos igual para referirse a las casas que habitarían los gentiles (Poma [1615, fs. 53, 54] 1987: 50, 51), que a las «bóvedas» en las que los indios depositan a sus difuntos (Poma [1615, fs. 69, 186 (188), 257 (259), 294 (296)] 1987: 65, 179, 248, 290), estructuras funerarias identificadas a su vez con torres-chullpas (Poma [1615, fs. 287 (289), 289 (291), 293 (295),

31 Resulta llamativo a este respecto el hecho de que los diferentes ogros andinos también suelan quedar caracterizados desde esta paradoja: al mismo tiempo que son representados como gentiles, antisociales, ejemplos de anticultura a quienes se niegan las artes culinarias, según distintas tradiciones, tienen morteros y piedras para moler quinua o maíz, cocinan su propia comida, preparan sopa, una sopa en la que hierven a sus víctimas, y en muchas ocasiones -como enseguida veremos que les ocurre a los chullpas- mueren devorados por el fuego, esto es, cocinados. Así ocurre, entre otras tradiciones, en Santiago, con los chaka abuelos, asimilables él al Wakón y ella a la Mama Huaco o la Achiké (Gil 2008: 173-191) 
295 (297)] 1987: 285, 287, 291, 293). No voy aquí a ahondar en el problema de esta asociación entre las estructuras chullparias (monumentos funerarios) y las unidades domésticas desde el punto de vista de la interpretación arqueológica (cfr. Gil 2001: 186-189), al cual se añade además un problema léxico derivado del empleo de este concepto de pucullo, glosado por los cronistas en términos de bóveda, pero bóveda de horno, muchas veces refiriéndose a estas chullpa-pucullo como «hornitos de piedra». Así, casas-horno donde los chullpas buscaron refugio de un sol/fuego que terminó cocinándoles dentro, y que las transformó en casas-tumba ${ }^{32}$. Pero más aún -tal como apuntan J. Ansión (1987: 88-91) y C. Itier (2007: 28)-, no perdamos de vista lo tentador que para el catequista colonial habría resultado este mito de los gentiles abrasados en sus casas como castigo (divino) a su rebeldía, su prepotencia y/o su mezquindad. Los gentiles, antepasados paganos de los indios, de diabólicas costumbres, antítesis del ideal de vida cristiano, ardiendo en el Infierno por sus pecados. Un Infierno, no lo perdamos de vista, tantas veces representado desde el referente folklórico de las calderas de Pedro Botero, grandes ollas donde los pecadores son cocinados al tiempo que horripilantes diablos les someten a todo tipo de tormentos. Así, una vez más, la cocina actuando de bisagra entre la otredad chullpa y la identidad de las actuales gentes andinas: su cocinado final domestica, civiliza e incluso redime simbólicamente a los chullpas como paso previo a su condenación eterna; la sal del bautismo, recordémoslo, libera a los humanos de la gentilidad que aún arrastran al nacer y les protege contra los chullpas.

Sin perder de vista esta discusión en torno a lo crudo y lo cocido, regresemos a las diferencias entre la cocina de los chullpas y la de la gente.

\section{Hígado muy pasado, carne cruda y antropofagia}

Es habitual que tras la celebración de un costumbre ciertas partes del animal sacrificado y el sobrante del banquete comunitario sean repartidos (obsequiados por el pasante) entre todos los asistentes según ciertos códigos de protocolo. En el reparto que siguió a la celebración del llamado de lluvia anual de 2004, a mi compadre Justino Calcina le correspondieron algunas tajadas de carne de llama, y parte del hígado del animal, que cenaríamos en familia esa misma noche. Dejándome llevar por mis evocaciones gastronómicas, se me hizo la boca agua pensando en un filete de hígado gordito y jugoso, vuelta y vuelta y al punto de sal. Pero la decepción debió de notárseme en la cara cuando me sirvieron un delgado filete tan pasado que más bien parecía un crujiente de hígado. Ante la pregunta de si es que acaso no me gustaba traté de disimular explicando mis preferencias a la hora de cocinar la carne: "poco hecha». Los niños se miraron entre sí, apuntando, a pesar de la mirada réproba de su madre,

32 Muy gráficamente, J. Ansión (1987: 87) cita una versión del mito del final de los chullpas en Ayacucho (Perú) en la que se menciona que sus casas no fueron suficiente para protegerlos del diluvio de fuego que les estaba siendo enviado como castigo; más al contrario, en ellas murieron secándose «como chancho asado». Precisamente cerdo, con todas las implicaciones que existen a la hora de identificarlo como uno de los platos favoritos de los chullpas como entidades tutelares en el presente (v.gr. Fernández 1997: 206-208; 2004: 189197; López 2001: 113; Spedding 1993: 61-64). 
aquello de «ah, como chullpa come». Entonces mi comadre Eva Quispe me preguntó si en España todos sabíamos comer la carne así. Cuando yo respondí que eso dependía del gusto de cada uno, y de la carne en cuestión, pero que sí, que mucha gente, ella y Justino se miraron cómplices al tiempo que Becker ( 9 años) abría ojos como platos y sentenciaba reflexivo «tantos chullpas en España...». Conclusión: para los santiagueños, los chullpas comían carne cruda; otro apunte más a esa discusión previa sobre lo crudo y lo cocido en la cocina de los chullpas, y de los Andes en general.

Si anteriormente citaba esa máxima de que en los Andes nada se come crudo, cabría decir que la carne en particular es quizás el alimento que más cocinado se toma, ya sea hervida en sopas o guisos, asada o frita, siempre «muy hecha». El andino apunta J. Ossio (1988: 569)- nunca aceptará una carne «poco hecha» (cruda), algo que «le produce una profunda repugnancia».

Que los chullpas coman sin sal les aleja de la condición humana, que se alimenten de esas especies «espejadas» les convierte en silvestres, en seres naturales, que tomen los alimentos crudos les vuelve bárbaros o incluso salvajes. Pero si hay algo que (alimenticiamente hablando) los denigre en tanto que salvajes bestiales, eso es sin duda la antropofagia, por más que ésta se halle ligada a situaciones extraordinarias y excepcionales como pueda ser la guerra o la hambruna. Una antropofagia que en el caso de la comunidad de Santiago, por ejemplo, siempre aparece ligada a los «tiempos de la gentilidad» $\mathrm{y} / \mathrm{o}$ a todos aquellos seres que son catalogados como gentiles en sentido extenso ${ }^{33}$. De los chullpas en particular, charlando sobre la «guerra antigua» y la dureza de los asedios (Gil 2005: 205-211), Justino Calcina (41 años, 2002) me diría:

«Entonces vivían en una vida de herejía, o sea que eran herejes, que no eran cristianos; que a veces entre ellos se comían, que a veces se le comían al más flojo. Bueno, etc. Que comían también carne humana».

Según la descripción de mi compadre, esta práctica canibalesca tendría su explicación de ser en lo prolongado de unos asedios que procuraban acabar con el enemigo desabasteciéndolo de agua y comida, y una resistencia numantina de los chullpas que preferían comerse entre ellos o a los enemigos capturados antes que rendirse. Guerra y hambre, en definitiva.

En términos aproximados, al comentar la mezquindad de los chullpas de Marcapata (Quipiscanchis, Perú), ya señalé cómo al saber que iban a morir prefirieron destruir su menaje de cocina y arrojar sus provisiones a los pedregales antes que dejarlos para la humanidad venidera; calcularon mal los tiempos, el Sol se retrasó en hacer acto de presencia, y empezó a cundir el hambre entre ellos. Llegados a este punto, los chullpas cocinaron a sus propios hijos (Sendón 2010: 153, 156). Con engaños los estaban cocinando, $\mathrm{y}$-recoge este autor- con crueldad tuvieron que rematarlos antes

33 A la hora de componer su memoria (histórica) y construir su identidad, resulta significativo el hecho de que aquellos momentos, acontecimientos y seres que pueblan el pasado de Santiago, y frente a los cuales se posicionan éticamente los santiagueños, quedan marcados, de un modo u otro, por la antropofagia o el sacrificio humano: los chullpas, valerosos capitanes entregados a la guerra total, se devoraban entre sí; los antiguos santiagueños del tiempo de las guerras de independencia fueron capaces de arrancar de las entrañas de su madre un feto humano para ofrecérselo al Tío a cambio de poner a salvo la mina que proveía de riqueza a la comunidad; los chaka abuelos, arquetipo del afuerino antisocial, asesinan a los viajeros para devorarlos, $\mathrm{y} / \mathrm{o}$ les ofrecen a comer «sopa de gente». 
de poder comérselos. Y es que -como apunta A. Spedding (1993: 162-164)-asociada al canibalismo va siempre una muerte cruel y violenta.

\section{Consideraciones finales}

Cocina desabrida, cultivo de alimentos silvestres, el asunto de la cebolla y el de la sopa, la carne cruda, la antropofagia en situación extrema, éstas son las claves que permiten plantear una suerte de antropología de la alimentación para los chullpas desde la tradición de Santiago (Nor Lípez, Potosí, Bolivia). Las mismas, más o menos, a pesar de los matices y las sutilezas, que encontramos en distintas tradiciones andinas, sin perder de vista la cuestión fundamental de si los chullpas tuvieron capacidad de cocinar o no. Un reducido catálogo de coincidencias al que, sin embargo, las etnografías no han prestado especial atención; en algunas se dedica cierta atención puntual a alguna de estas cuestiones, en otras simplemente se mencionan, en la mayoría pasan inadvertidas.

En el fondo, pareciera que conocemos a los chullpas más por lo que no son que por lo que son, más por lo que les diferencia de nosotros que por lo que ellos mismos se suponen que fueron, se supone que son, y en cuanto a su cocina se refiere, no me cabe la menor duda de que es así. Ríos de tinta han corrido sobre cómo los especialistas rituales se relacionan, culinariamente hablando, con los chullpas, sobre los ingredientes que componen las mesas ceremoniales, sobre sus comidas favoritas, sobre si estas mesas constituyen en realidad un trueque o una pagancia. Por el contrario, creo que tratar de definir a los chullpas a partir de su cocina y su comida (las propias de ellos, no los platos que el especialista ritual les presenta hoy), caracterizar su tiempo y sus espacios desde la alimentación, son temas aún pendientes. Y eso es lo que a través de estas páginas que terminan he pretendido hacer, tomando la alimentación en los Andes como un telón de fondo sobre el cual proyectar, y desde el cual interpretar, una serie de lecturas entrelíneas, cabos sueltos, ejemplos aislados, anécdotas del trabajo de campo, del mío propio y del de otros. Desde esta perspectiva, nada más lejos de mi intención llegar a perfilar una serie de reglas generales, sino más bien empezar a organizar ese catálogo al que antes me refería con el suficiente criterio interpretativo como para poder avanzar en la discusión. En este sentido, no me importará haber tal vez pecado de gula en el modo de componer estas páginas si al final fueran digeridas como un llamado de atención sobre la relevancia del tema y su potencial en el estudio del pasado andino y sus habitantes.

\section{Referencias bibliográficas}

Abercrombie, Thomas A.

2006 Caminos de la memoria y del poder. Etnografía e historia de una comunidad andina [1998]. La Paz: Instituto Francés de Estudios Andinos - Instituto de Estudios Bolivianos - ASDI

ABsi, Pascale

2005 Los ministros del diablo. El trabajo y sus representaciones en las minas de Potosí 
[2003]. La Paz: Fundación PIEB - Instituto de Investigaciones para el Desarrollo - Instituto Francés de Estudios Andinos - Embajada de Francia en Bolivia.

Allen, Catherine J.

1982 «Body and Soul in Quechua Thought». Journal of Latin American Lore 8 (2): 179196.

1984 «Patterned Time: The Mythic History of a Peruvian Community». Journal of Latin American Lore 10 (2): 151-173.

Ansión, Juan

1987 Desde el rincón de los muertos. El pensamiento mítico en Ayacucho. Lima: Publicaciones GREDES (Grupo de Estudios para el Desarrollo).

Arguedas, José María

1960-61 «Cuentos religiosos-mágicos quechuas de Lucanamarca». Folklore Americano 8-9: 142-216. Lima.

Arnold, Denise Y., Domingo JimÉnez Arequipa y Juan de Dios Yapita

1998 «Simillt'aña: pensamientos compartidos acerca de algunas canciones a los productos de un ayllu andino», en Hacia un orden andino de las cosas, D. Arnold, D. Jiménez y J. D. Yapita, eds., pp. 109-173. La Paz: Hisbol - ILCA.

Bouysse-Cassagne, Thérèse y Olivia Harris

1987 «Pacha: en torno al pensamiento aymara», en Tres reflexiones sobre el pensamiento andino, de T. Bouysse-Cassagne, O. Harris, T. Platt y V. Cereceda, pp. 11-59. La Paz: Hisbol.

CAmacho, Juana

2006 «Bueno para comer, bueno para pensar. Comida, cultura y biodiversidad en Cotacachi», en Desarrollo con identidad: comunidad, cultura y sustentabilidad en los Andes, R. Rhoades, ed., pp. 1-26. Quito: Abya-Yala.

CAsaverde Rojas, Juvenal

1970 «El mundo sobrenatural en una comunidad». Allpanchis 2: 212-243.

Cavalcanti-Schiel, Ricardo

2007 «Las muchas naturalezas en los Andes». Perifèria 7: 1-11. Barcelona.

CEReCEDA, Verónica

1990 «A partir de los colores de un pájaro». Boletín del Museo Chileno de Arte Precolombino 4: 57-104.

Dillon, Mary y Thomas ABercrombie

1988 «The Destroying Christ: An Aymara Myth of Conquest», en Rethinking History and Myth. Indigenous South American Perspectives on the Past, J. D. Hill, ed., pp. 50-77. Urbana: University of Illinois Press.

Duviols, Pierre

1974-76«Une petite chronique retrouvée: Errores, ritos, supersticiones y ceremonias de los yndios de la prouincia de Chinchaycocha y otras del Piru». Journal de la Société des Américanistes 62: 275-297.

FERNÁNDEZ JuÁREZ, Gerardo

1995 El banquete aymara. Mesas y yatiris. La Paz: Hisbol.

1997 Entre la repugnancia y la seducción. Ofrendas complejas en los Andes del sur. Cuzco: Centro de Estudios Regionales Andinos «Bartolomé de Las Casas». 
2004 Yatiris y ch'amakanis del altiplano aymara. Sueños, testimonios y prácticas ceremoniales. Quito: Abya-Yala.

Gil García, Francisco M.

2001 «Secuencia y consecuencia del fenómeno chullpario. En torno al proceso de semantización de las torres chullpa». Anales del Museo de América 9: 165-199.

2005 «Batallas del pasado en tiempo presente: 'guerra antigua', civilización y pensamiento local en Lípez (Dpto. Potosí, Bolivia)». Bulletin del IFEA 34 (1): 1-24.

2008 «Un pueblo sitiado. Miedos y entidades terribles en la construcción del espacio social de una comunidad surandina», en Antropologías del miedo. Vampiros, sacamantecas, locos, enterrados vivos y otras pesadillas de la razón, G. Fernández Juárez y J. M. Pedrosa, eds., pp. 145-196. Madrid: Calambur.

2011 «Lo que a nadie asusta pero a todos preocupa. Etnografía de los miedos cotidianos de una comunidad del altiplano sur boliviano». RELEA. Revista Latinoamericana de Estudios Avanzados 17 (33): 59-95.

Gow, Rosalin y Bernabé CondorI

1982 Kay Pacha. Cuzco: Centro de Estudios Rurales Andinos «Bartolomé de Las Casas».

GutiÉRrez EstÉvez, Manuel

1988 «Hipótesis y comentarios sobre la significación de la Mama-Huaca», en Mito y ritual en América, M. Gutiérrez, comp., pp. 286-323. Madrid: Alhambra.

ITIER, Cesar

2007 El hijo del oso. La literatura oral quechua de la región del Cuzco. Lima: Instituto Francés de Estudios Andinos - Instituto de Estudios Peruanos - Pontificia Universidad Católica del Perú - Universidad Nacional Mayor de San Marcos.

LóPEZ GARCÍA, Julián

2001 «Comida y bases de la identidad aymara en el altiplano de Bolivia», en Alimentación y sociedad en Iberoamérica y España. Cinco etnografías de la comida y la cocina: 97-120. Cáceres: Universidad de Extremadura - Caja Duero.

2008 «Nuevos temas y nuevas perspectivas en los estudios culturales de la comida», en Bocas compartidas. Alimentación, salud y tradiciones populares, E. Barcia, coord., pp. 77-100. Mérida: Universidad de Extremadura - Junta de Extremadura.

MARTínEZ, Gabriel

2001 «Saxra (diablo) / Pachamama. Música, tejido, calendario e identidad entre los jalq'a». Estudios Atacameños 21: 133-151.

Nuñez DEL PRADO, Óscar

1957 El hombre y la familia. Su organización político-social en Q'ero. Cuzco: Garcilaso.

Ossio, Juan M.

1988 «Aspectos simbólicos de las comidas andinas». América Indígena 48 (3): 549570. [Publicado simultáneamente en Alimentación iberoamericana: símbolos y significados, M. Gutiérrez, comp., pp. 89-110. Trujillo - México: Fundación Xavier de Salas - Instituto Indigenista Interamericano].

Pazzarelli, Francisco

2010 «La importancia de hervir la sopa. Mujeres y técnicas culinarias en los Andes». Antípoda. Revista de Antropología y Arqueología 10: 157-181. 
Platt, Tristan

1986 «Mirrors and Maize: The Concept of Yanantin among the Macha of Bolivia», en Anthropological History of Andean Polities, J. Murra, N. Wachtel y J. Revel, eds., pp. 228-259. Cambridge: Cambridge University Press.

2001 «El feto agresivo. Parto, formación de la persona y mito-historia en los Andes». Anuario de Estudios Americanos 58 (2): 633-678.

Poma DE Ayala, Felipe Gaumán

1987 Nueva crónica y buen gobierno [1615], edición de J. Murra, R. Adorno y J. L. Urioste. Crónicas de América 29 a-c. Madrid: Historia 16.

Pomeroy, Cheryl

1988 «The Salt of Highland Ecuador: Precious Product of a Female Domain». Ethnohistory 35 (2): 131-160.

RASNAKE, Roger

1988 «Images of Resistance to Colonial Domination», en Rethinking History and Myth. Indigenous South American Perspectives on the Past, J. D. Hill, ed., pp. 136-156. Urbana: University of Illinois Press.

RicARD LANATA, Xavier

2007 Ladrones de sombra. El universo religioso de los pastores del Ausangate. Lima: IFA - CBC.

Rivera ANDíA, Juan Javier

2000 «Los gentiles de Llampa». Anthropologica 18: 271-280. Lima.

2006 «Mitología en los Andes», en Mitologías amerindias, A. Ortiz ed., pp. 129-176. Madrid: Trotta.

Robin AzEvedo, Valérie

2008 Miroirs de l'autre vie. Pratiques rituelles et discours sur les morts dans les Andes de Cuzco (Pérou). Nanterre: Société d'Ethnologie.

Rostworowski, María

2005 «Los ayarmaca», en Obras completas V: Ensayos de historia andina I: Elites, etnias, recursos, pp. 212-248. Lima: Instituto de Estudios Peruanos.

SENDÓn, Pablo F.

2010 «Los límites de la humanidad. El mito de los ch'ullpa en Marcapata (Quipiscanchi), Perú». Journal de la Société des Américanistes 96 (2): 133-179.

SPEDDING, Alison

1993 «Semiótica de la cocina paceña o 'porquerías que nos hacen pasar por comida'. (Un bosquejo inicial)». Revista Unitas 10: 51-64. La Paz.

1994 Wachu Wachu. Cultivo de la coca e identidad en los Yunkas de La Paz. La Paz: Hisbol - COCAYAPU - CIPCA.

TSCHOPIK, Harry

1948 «Aymara Texts: Lupaca Dialect». International Journal of American Linguistics 14 (2): 108-114.

Voces de la tierra

2010 Voces de la Tierra. Relatos sobre montañas y lagunas. Lima: Instituto Nacional de Cultura. 
Weismantel, Mary J.

1994 Alimentación, género y pobreza en los Andes ecuatorianos. Quito: Abya-Yala.

WÖRRLE, Bernhard

1999 De la cocina a la brujería. La sal entre los indígenas y mestizos en América Latina. Quito: Abya-Yala.

Zuidema, R. Tom y Gary URTON

1976 «La constelación de la Llama en los Andes peruanos». Allpanchis Puthurinqa IX: 59-119. 